\title{
A Study of Chemical Composition and Enzymatic Hydrolysis of Solid Organic Waste from Agrosilvopastoral Systems
}

\author{
Fiama M. Cutrim, ${ }^{\circledR *, a}$ Emily C. S. S. Ramos, ${ }^{b}$ Milena C. C. Abreu, ${ }^{b}$ Allan S. Godinho, ${ }^{b}$ \\ Adeilton P. Maciel, ${ }^{c}$ Cáritas J. S. Mendonça ${ }^{c}$ and Kiany S. B. Cavalcante ${ }^{b}$ \\ ${ }^{a}$ Departamento de Química, Universidade Federal de São Carlos, Rod. Washington Luís, km 235, \\ 13565-905 São Carlos-SP, Brazil \\ ${ }^{b}$ Instituto Federal de Educação Ciência e Tecnologia do Maranhão, Av. Getúlio Vargas, \\ Monte Castelo, 65030-005 São Luís-MA, Brazil \\ 'Departamento de Química, Universidade Federal do Maranhão, Av. dos Portugueses, 1966, \\ Vila Bacanga, 65080-805 São Luís-MA, Brazil
}

\begin{abstract}
Agrosilvopastoral waste, regarding agriculture and agro-industry sectors, is pointed as a promising sustainable raw material for biofuels production, specially concerning exploitation of lignocellulosic organic residues for fermentable sugars and cellulosic ethanol output, being therefore necessary to investigate the potential of these substrates concerning chemical composition, since many of them were not reported yet in literature. Being so, this paper presents a study of chemical composition and enzymatic hydrolysis of wastes from the four main crops in Maranhão, Brazil (soy, cassava, rice and corn) which are usually underutilized or abandoned in the field. The results of enzymatic hydrolysis were satisfactory for both soy and particularly corn residues, which presented total reducing sugars (TRS) percentage greater than 50\% in comparison with pure cellulose.
\end{abstract}

Keywords: lignocellulosic residues, corn residues, fermentable sugars

\section{Introduction}

In Maranhão, Brazil, the Solid Waste Management Plan (PEGRS) estimates an elevated production of residual biomass generated in regional agro-industries, classified as permanent and temporary macro crops. ${ }^{1}$ In 2010 , the appraised amount of agrosilvopastoral waste I (organic waste) generation in agro-industries in Maranhão was almost 3.8 millions of tons. ${ }^{1}$

The inappropriate disposal of these wastes favors environmental impacts occurrence, that can affect areas beyond the surroundings of where the anthropic action happens, like deposition in rivers and open burning. ${ }^{2}$ Recycling not only minimizes the impacts, but is also an alternative to reduce natural resource and energy losses, converting the inputs in higher value-added products, such as biofuels, and thus promoting a positive regional impact, like employment and income generation.

Lignocellulosic biomass is composed mainly by: cellulose (35-50\%), a biopolymer consisting of glucose

*e-mail: fiamacutrim@acad.ifma.edu.br units linked by $\beta$-1,4-glycosidic bonds; hemicellulose (20-35\%), formed by different hexoses (glucose, mannose, rhamnose and galactose) and pentoses (xylose and arabinose) linked by $\beta-1,4$ - and $\beta$-1,3-glycosidic bonds; and lignin (10-25\%), non-carbohydrate component formed from three basic precursors, $p$-coumaryl, coniferyl and sinapyl alcohols. ${ }^{3}$ The latter encapsulates cellulose and hemicellulose giving them greater chemical, mechanical and biological resistance. ${ }^{4}$ The lignocellulosic biomass recalcitrance is also due to cellulose crystallinity and lignin hydrophobicity. ${ }^{4}$

In the conversion of residual cellulose to higher valueadded products, the production of fermentable sugars and cellulosic ethanol, also known as second generation $(2 \mathrm{G})$ ethanol, is highlighted from the hydrolysis of cellulose $\beta$-1,4-glycosidic bonds resulting in monosaccharide and/or oligosaccharide molecules. ${ }^{5}$

Throughout time, researchers focused their studies on hydrolysis by homogeneous acid catalysts. ${ }^{6}$ However, to work around disadvantages such as reactor corrosion and easy byproducts output, the acids were replaced by cellulolytic enzymes able to perform cleavage of 
the glycosidic bonds with specificity in front of the substrates and products. ${ }^{7}$ Cellulase enzymes, such as those derived from lignocellulolytic fungi of the species Trichoderma reesei, Aspergillus niger, Aspergillus nidulans and Penicillium funiculosum, are more selective and competitive to hydrolyze cellulose into monosaccharides, such as glucose. ${ }^{8}$

With the prospect of providing a study on the use and management of residues, this research investigated the chemical composition of residues of the four main crops in Maranhão, Brazil: soybean, cassava, rice and corn. The information about characterization is important to propose usefulness for these lignocellulosic wastes and understand its chemical derivatives. Then, a study of the cellulose degradation was carried out through an enzymatic hydrolysis process to evaluate the application of these biomasses for the production of fermentable sugars.

\section{Experimental}

\section{Collecting and characterization}

Residues of soybean, cassava, rice and corn, collected in family farms in Maranhão, were dried at room temperature for $24 \mathrm{~h}$. Then, they were crushed in a rotor mill cyclone type (Tecnal, 651/2) and sieved to 20 mesh.

To determine lignin, cellulose and hemicellulose contents, the grinded biomasses were subjected to a Soxhlet extraction, to remove interferents, using solvent hexaneethanol (1:1) until complete pigment elimination. Then, $2 \mathrm{~g}$ of each extractive-free material was treated with $10 \mathrm{~mL}$ of $72 \% \mathrm{H}_{2} \mathrm{SO}_{4}$ maintained in a thermostatic bath (Fisaton) at $45^{\circ} \mathrm{C}$ for $7 \mathrm{~min}$ and then autoclaved (vertical autoclave, CS Prismatec) at $121{ }^{\circ} \mathrm{C}$ for 30 min with $285 \mathrm{~mL}$ of $4 \%$ $\mathrm{H}_{2} \mathrm{SO}_{4}$, according to Gouveia et al. ${ }^{9}$ methodology.

Insoluble lignin content was determined by gravimetry of insoluble residue dry mass retained in filtration. Filtration aqueous hydrolysate was analyzed for: (i) soluble lignin by UV-Vis spectrophotometry at $280 \mathrm{~nm}$ (Shimadzu, UV-1800); (ii) cellulose and hemicellulose, from saccharides and acids analysis (cellobiose, glucose, xylose, arabinose and acetic acid) by high-performance liquid chromatography with refractive index detector (HPLC-RID, Shimadzu, LC-20AD) using an Aminex ${ }^{\circledR}$ HPX 87H column (Bio-Rad, $300 \times 7.8 \mathrm{~mm}$ ) and $0.005 \mathrm{~mol} \mathrm{~L}^{-1} \mathrm{H}_{2} \mathrm{SO}_{4}$ as mobile phase, at $50{ }^{\circ} \mathrm{C}$ and flow rate of $0.8 \mathrm{~mL} \mathrm{~min}^{-1}$, and from furfural and 5-hydroxymethylfurfural (HMF) analysis using a Shim-pack CLC-ODS(M)® C18 column (Shimadzu, $250 \times 4.6 \mathrm{~mm}$ ), diode array detector (HPLC-DAD) and mobile phase of $0.1 \%$ formic acid:acetonitrile $(40: 60, \mathrm{v} / \mathrm{v})$ at $35^{\circ} \mathrm{C}$ and flow rate of $0.6 \mathrm{~mL} \mathrm{~min}{ }^{-1}$. The concentrations used, the coefficients of determination and linear equations for hydrolysis products are shown in Table 1.

Ash and moisture content were determined by gravimetry in a muffle furnace (ZEZIMAQ) at $550{ }^{\circ} \mathrm{C}$ for $2 \mathrm{~h}$ and stove (LUCADEMA) at $105^{\circ} \mathrm{C}$ for $3 \mathrm{~h}$, respectively, and protein was characterized by Kjeldahl method. ${ }^{10}$ All measurements were made in triplicate.

\section{Pretreatment}

A $0.5 \mathrm{~g}$ aliquot of each dry and crushed biomass underwent pretreatment with $50 \mathrm{~mL}$ of $0.5 \mathrm{~mol} \mathrm{~L}^{-1}$ sulfuric acid in a high pressure reactor (Parr 4848) under continuous stirring at $170^{\circ} \mathrm{C}$ for $8 \mathrm{~min}$, and then filtered, water-washed until $\mathrm{pH} 6.0$ and then dried at room temperature.

The in natura and pretreated biomasses were analyzed by a scanning electron microscope (SEM, Hitachi, model TM3030) with light magnification range of 20-120x, electron magnification range of $80-130,000 \times$, tungsten filament and acceleration voltage of $15 \mathrm{kV}$.

\section{Enzymatic hydrolysis}

The enzymatic conversion study was performed in test tubes, using $0.1 \mathrm{~g}$ of pretreated biomass containing granules greater than $20 \mathrm{mesh}, 5 \mathrm{~mL}$ of $0.1 \mathrm{~mol} \mathrm{~L}^{-1}$ sodium citrate, $5 \mathrm{~mL}$ of $1 \mathrm{~mol} \mathrm{~L}^{-1}$ citric acid (pH ca. 5.0) and $0.06 \mathrm{~mL}$ of hemicellulase enzyme Cellic ${ }^{\circledR} \mathrm{HTec} 2$, provided by Novozymes A/S. The tubes were stirred manually and

Table 1. Concentration curves for hydrolysis products

\begin{tabular}{lccc}
\hline Component & Concentration $/\left(\mathrm{g} \mathrm{L}^{-1}\right)$ & Coefficient of determination $\left(\mathrm{R}^{2}\right)$ & Linear equation \\
\hline D-(+)-Glucose (Sigma, 99.5\%) & $0.2-2.0$ & 0.9995 & $y=219972 x-9381.2$ \\
D-(+)-Xylose (Êxodo Científica) & $0.125-2.2$ & 0.9999 & $y=216543 x+899.64$ \\
L-(+)-Arabinose (Inlab) & $0.03-0.3$ & 0.9988 & $y=214278 x+39.675$ \\
Acetic acid (Sigma, 99\%) & $0.02-0.2$ & 0.9998 & $y=136504 x-123.7$ \\
Furfural (Sigma) & $0.005-0.5$ & 0.9981 & $y=22405667 x+239251$ \\
5-(Hydroxymethyl)furfural (Sigma, 99\%) & $0.025-0.8$ & 0.992 & $y=290258406.4 x+763624$ \\
\hline
\end{tabular}


taken to water bath at $50{ }^{\circ} \mathrm{C}$ for $48,72,96,120$ and $144 \mathrm{~h}$. The study was also performed with pure cellulose (Sigma-Aldrich) under the same conditions.

After determining the best reaction time, a study was carried out on the conversion of pretreated biomasses containing granules smaller than 20 mesh, under the same reaction conditions. The total reducing sugars (TRS) of hydrolyzed products was determined by Miller's ${ }^{11}$ method using a UV-Vis spectrophotometer (PerkinElmer, Lambda XLS) at $540 \mathrm{~nm}$ after being previously submitted to colorimetric assay by DNS reagent (3,5-dinitrosalicylic acid). ${ }^{12}$ The linear equation $y=0.7101 x-0.0203$ and coefficient of determination $\left(\mathrm{R}^{2}\right)=0.9999$ employed were provided through linear regression study for glucose.

Conversion of hydrolyzed biomass was expressed in TRS percentage using the equation $\mathrm{TRS}(\%)=\mathrm{m} / \mathrm{M} \times 100$ where $\mathrm{m}$ is the TRS mass $(\mathrm{g})$, determined by $\mathrm{m}=\mathrm{c} \times \mathrm{V}$ ( $\mathrm{c}=$ concentration; $\mathrm{V}=$ volume), and $\mathrm{M}$ is the mass $(\mathrm{g})$ of biomasses prior to hydrolysis.

Identification and quantification of glucose in hydrolyzed products were performed by chromatographic analysis using an HPLC-RID with a Phenomenex SphereClone ${ }^{\mathrm{TM}}$ column with an $80 \AA \mathrm{AH}_{2}$ stationary phase $(5 \mu \mathrm{m}, 250 \times 4.6 \mathrm{~mm})$, acetonitrile:water $(75: 25, \mathrm{v} / \mathrm{v})$ as mobile phase at $45{ }^{\circ} \mathrm{C}$ and flow rate of $0.8 \mathrm{~mL} \mathrm{~min}{ }^{-1}$. The linear equation and coefficient of determination was $y=214873 x-8788.4$ and $\mathrm{R}^{2}=0.9983$, respectively, for glucose.

\section{Results and Discussion}

\section{Lignocellulosic organic residues}

In Maranhão (Brazil), agrosilvopastoral residues I are usually underutilized or abandoned in the field generating a large amount of waste. ${ }^{1}$ The generation of wastes was 965.3 thousands of tons of soy, 308.9 thousands of tons of corn, 889.4 thousands of tons of sugar cane and 1.4 millions of tons of cassava at $2010 .^{1}$
Particularly, the byproducts of cassava culture include roots, peel and pulp. The residue of peel is composed by epidermis (an external brown peel with lignocellulosic composition) and cortex (a white middle peel with starch composition), but it is also common the discard of pulp (starch parenchyma). Some farmers in Maranhão use only sweet manioc (also known as cassava) residues, which have low hydrocyanic acid content (below $180 \mathrm{mg} \mathrm{kg}^{-1}$ of $\mathrm{HCN}$ on a wet basis), in animals feeding. ${ }^{13}$ In this work, the cassava byproduct used to conversion in fermentable sugars was the cassava epidermis due to its lignocellulosic composition.

Evaluation of biomasses chemical composition is indispensable, particularly regarding the cellulose amount available for conversion into fermentable sugars. High content of cellulose is suitable for the enzymatic hydrolysis of this polysaccharide into glucose. Table 2 presents the chemical composition study results for these organic solid wastes, in terms of cellulose, hemicellulose, lignin, protein and ash contents together with the coefficient of variation (CV) on the right of the measures obtained from dry matter content. The percentage of unquantified material is also shown in Table 2 titled as others.

The lignocellulosic solid residues corn cob and corn straw under study presented high content of cellulose and hemicellulose, main polysaccharides in plants cell walls. There was greater evidence of cellulose in corn straw, which favors the study of conversions into glucose by hydrolysis reaction.

The high contents of glucose (from cellulose) and xylose (from hemicellulose) is very positive in the perspective of production of $2 \mathrm{G}$ ethanol because cellulose (homopolysaccharide with the $\beta$-1,4-glycosidic linkage of glucose) is the main source of carbon for the bioconversion of lignocellulosic wastes and the hemicellulose is more accessible than cellulose due to its amorphous structure constituted by pentose (xylose and arabinose), hexose (glucose, mannose and galactose) and acids of sugar (aldonic and oxalic acid). ${ }^{14,15}$

Table 2. Chemical composition lignocellulosic solid residues

\begin{tabular}{lccccc}
\hline Parameter & Soy peel & Cassava peel & Rice peel & Corn straw & Corn cob \\
\hline Dry mass / \% & $93.81 \pm 0.35$ & $95.3 \pm 0.41$ & $93.60 \pm 0.30$ & $92.29 \pm 0.35$ & $88.12 \pm 0.78$ \\
Cellulose / \% & $22.38 \pm 1.52$ & $24.2 \pm 1.2$ & $30.57 \pm 1.29$ & $36.22 \pm 1.55$ & $28.02 \pm 2.29$ \\
Hemicellulose / \% & $12.98 \pm 1.87$ & $4.9 \pm 0.08$ & $14.45 \pm 0.29$ & $28.07 \pm 3.48$ & $26.78 \pm 0.89$ \\
Total lignin / \% & $17.48 \pm 0.81$ & $50.7 \pm 0.53$ & $29.72 \pm 0.19$ & $21.89 \pm 0.84$ & $21.74 \pm 1.42$ \\
Ash / \% & $6.66 \pm 0.19$ & $8.33 \pm 0.5$ & $14.49 \pm 0.19$ & $1.60 \pm 0.06$ & $1.07 \pm 0.13$ \\
Protein / \% & $6.91 \pm 0.22$ & - & $5.34 \pm 0.52$ & $2.66 \pm 0.08$ & $9.24 \pm 0.78$ \\
Others / \% & 33.59 & 20.11 & 5.47 & 9.56 & 13.15 \\
\hline
\end{tabular}


The biomasses rice and cassava presented a high content of lignin, a macromolecule whose function is to confer rigidity, impermeability and natural resistance to microbiological and mechanical attacks on plant tissues. ${ }^{3}$ Rice and cassava wastes showed percentages above the $25 \%$ reported in the literature ${ }^{16}$ for biomasses in general. Particularly for cassava peel, this constituent showed to be the majority in comparison to cellulose and hemicellulose. Hemicellulose content in cassava peel was the poorest of all analyzed biomasses, which suggests that cassava peel is not the most indicated for xylose conversion in $2 \mathrm{G}$ ethanol. This substrate showed a high chemical and thermal resistance indicated by a total lignin percentage of $50.7 \%$, which is not in agreement with what was previously reported in literature, which presumes a percentage of $10-25 \%$ for this polymer in lignocellulosic biomass. However, there are few reports about this waste composition and the CV value of measures was smaller than $15 \%$, which indicates low dispersion of the analysis. ${ }^{17}$

Due to its protective action, lignin prevents enzymes' action in the cell wall, which requires a chemical pretreatment of the substrates for this fraction removal, increasing accessibility to cellulose. ${ }^{18}$ In addition, the high quantity of lignin is a disadvantage for the process, because it causes elevated formation of byproducts as phenolic compounds, which decreases the efficiency of enzymatic hydrolysis. ${ }^{19}$ Using diluted acid pretreatment in this biomasses is possible to modify the structure of the lignin content and remove part of hemicellulose. This method is used to promote the accessibility of enzymes in cellulose structure in enzymatic hydrolysis.

Ash content showed variations between different residues, particularly the rice peel with $14.49 \%$. Ashes from rice peels consist predominantly of silicon dioxide $\left(\mathrm{SiO}_{2}\right)$ and other low concentration oxides, such as potassium $\left(\mathrm{K}_{2} \mathrm{O}\right)$, magnesium $(\mathrm{MgO})$, phosphorus $\left(\mathrm{P}_{2} \mathrm{O}_{5}\right)$, sodium $\left(\mathrm{Na}_{2} \mathrm{O}\right)$, calcium $(\mathrm{CaO})$ and aluminum $\left(\mathrm{Al}_{2} \mathrm{O}_{3}\right) \cdot{ }^{20}$ Such a composition in addition to high percentage of ash makes rice peel a study source for catalytic and adsorbent activity. ${ }^{21}$

Traditionally in Maranhão, part of the lignocellulosic wastes available after harvest are burned and the cultivable soil is enriched by the ashes of the combustion, however, it causes the environmental impact of the gases emission of greenhouse effect in atmosphere. Liu and $\mathrm{BaO}^{22}$ consider the supplementation of cultivable soil using ashes of lignin combustion as an alternative fertilizer of phophorus and potassium, after the production of cellulosic ethanol.

The unquantified biomass content was high for soy peels (approximately $33.59 \%$ ). Some authors such as Mateus et al. ${ }^{23}$ reported the presence of lipids in soy peel.
The cellulose, main carbon source to bioconversion of lignocellulosic waste in fermentable sugars is associated to hemicellulose, pectin, protein and lignin. Pectin is also a complex polysaccharide of cell wall and is composed by homogalacturonan (HG), rhamnogalacturonan (RG-I), RG-II, and xylogalacturonan..$^{24}$ The high-unquantified content in soy is justified by other components of the cell wall. All measures presented CV values smaller than $15 \%$ which is considered as low dispersion. ${ }^{17}$

\section{Dilute acid pretreatment}

Conversion of lignocellulosic biomass into sugars relies on association between chemical and enzymatic treatments. Thus, biomass dilute acid pretreatment was used to reduce cell wall recalcitrance by depolymerization and solubilization of hemicellulose and lignin to ease enzymes access to cellulose on hydrolysis step. The constituent's disintegration promotes removal or alteration of lignin and hemicellulose, without degradation of the cellulosic chain. Lignin may still be present in biomasses even after chemical treatment due to its low solubility. ${ }^{18}$

Diluted acid coupled with high temperature and high pressure promotes darkening of all cellulosic biomasses. According to Santos et al.,$^{18}$ this darkening is associated with formation of carbohydrate degradation products as HMF.

SEM micrographs demonstrate that the in natura soy fibers have undergone structural changes on their surfaces. Longitudinal surfaces of in natura soy fibers show long continuous filaments (Figure 1a). After chemical treatment, fibers morphology reflects the modified biomass polysaccharide fraction, with irregular shape, little expansion and structure disorganization, evidenced by striations and crevices (Figure 1b).

The surface of in natura cassava peel shows morphology similar to plants cell walls structures. In Figure 2a, the parenchyma cells, formed by cells with thin primary walls consisting mainly of lignin, cellulose and hemicellulose, are distributed throughout the fiber. ${ }^{25}$ The transverse surface of pretreated cassava fiber (Figure $2 b$ ) demonstrates plant tissues fragmentation with cracks and vessels of different shapes and sizes.

Rice peel presented greater resistance to chemical process. Figure 3 shows the fibers morphology presenting some cracks, but at the same time, low depolymerization, which suggests the lignocellulosic constituents are still present.

Changes on treated corn straw surface could be noticed by the fiber characteristic recess, indicating biomass recalcitrance reduction. Micrographs pointed changes from 


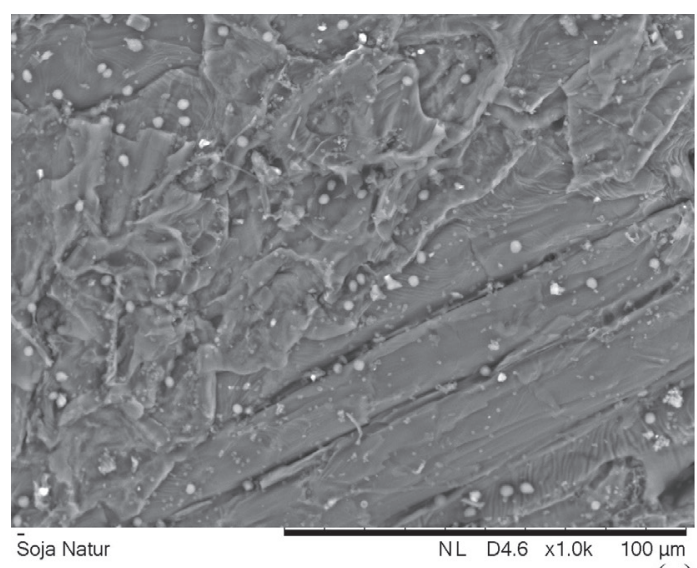

(a)

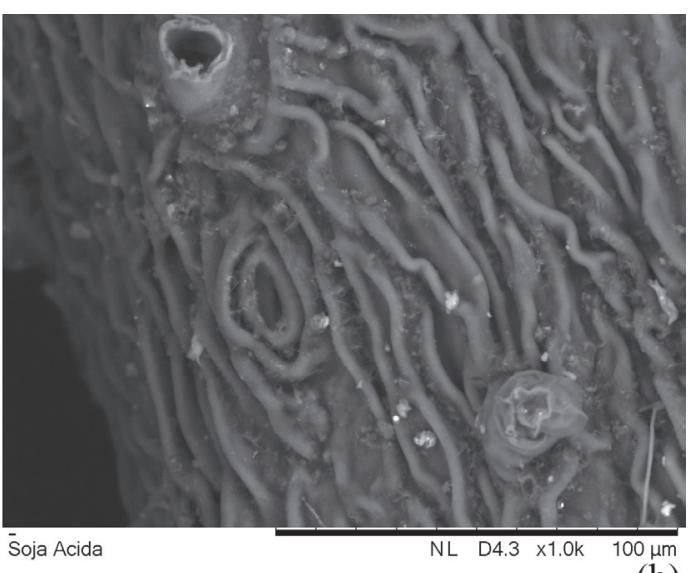

(b)

Figure 1. Micrograph of in natura (a) and pretreated (b) soy superficial structure.

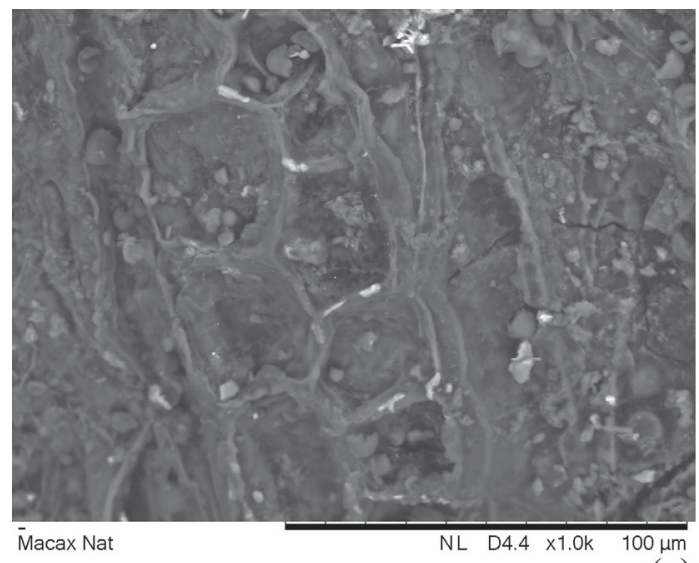

(a)

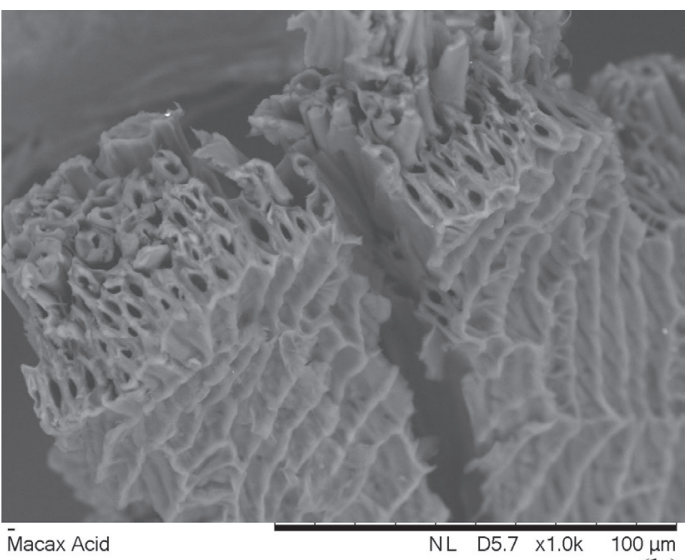

(b)

Figure 2. Micrograph of in natura (a) and pretreated (b) cassava superficial structure.

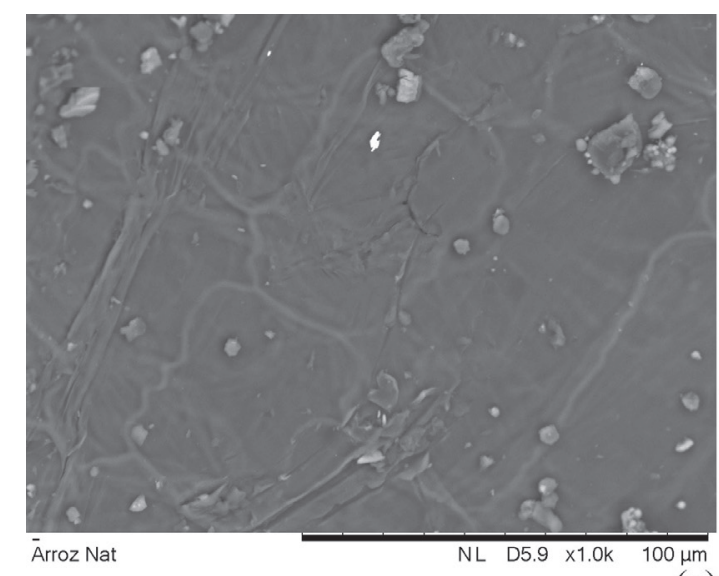

(a)

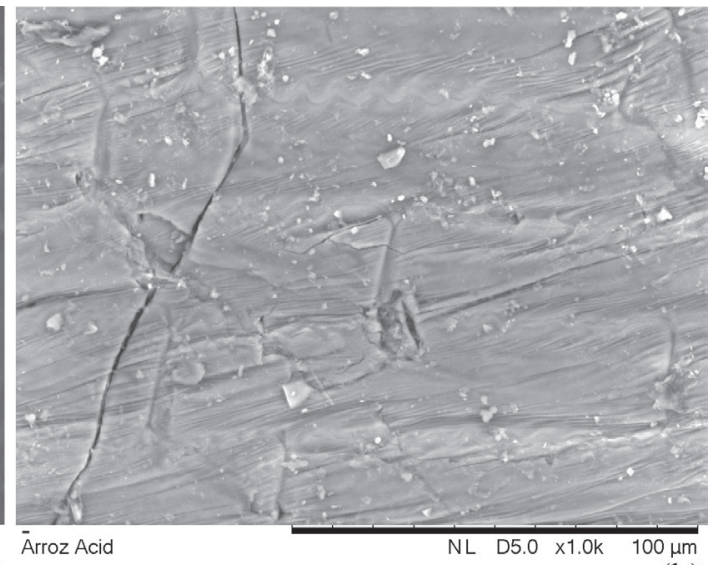

(b)

Figure 3. Micrograph of in natura (a) and pretreated (b) rice superficial structure.

a rigid texture along the plan (Figure 4a) to a prominent irregular texture presenting recesses and pores (Figure 4b), which reflects hemicellulose/lignin partial removal and reactive surface area increase. ${ }^{26}$

The in natura corn cob (Figure 5) presents external and internal surfaces with protrusions, orifices and regular spheres along its fibers, which is an indicative of starch granules ${ }^{27}$ Chemical process provokes changes on the cob surface, leading to formation of cavities and pores which causes the increase in superficial area. ${ }^{18}$

According to Mood et al. ${ }^{28}$ acid pretreatment promotes glycosidic bonds rupture, modifying plant cell wall 


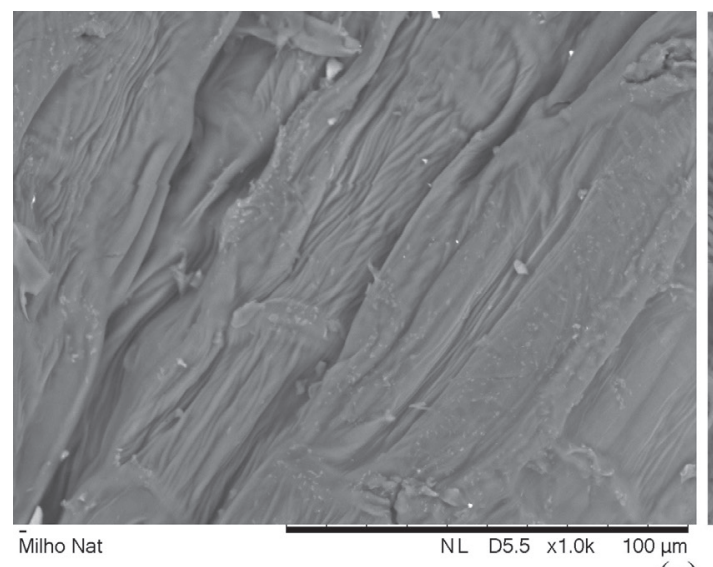

(a)

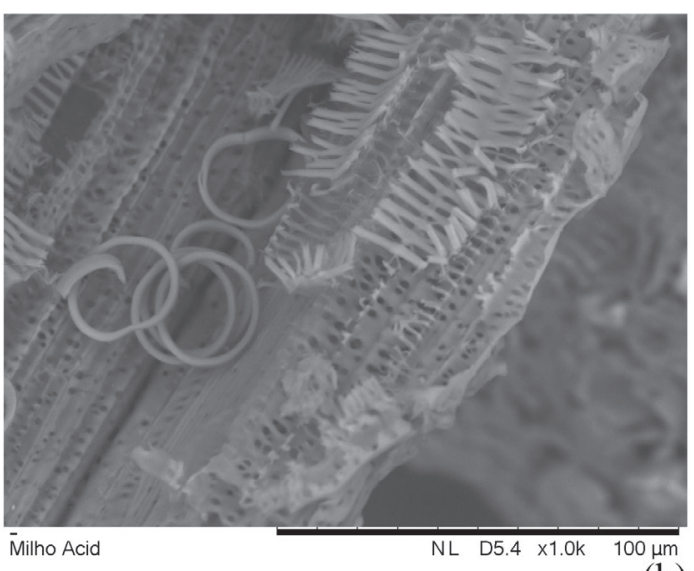

(b)

Figure 4. Micrograph of in natura (a) and pretreated (b) corn straw superficial structure.

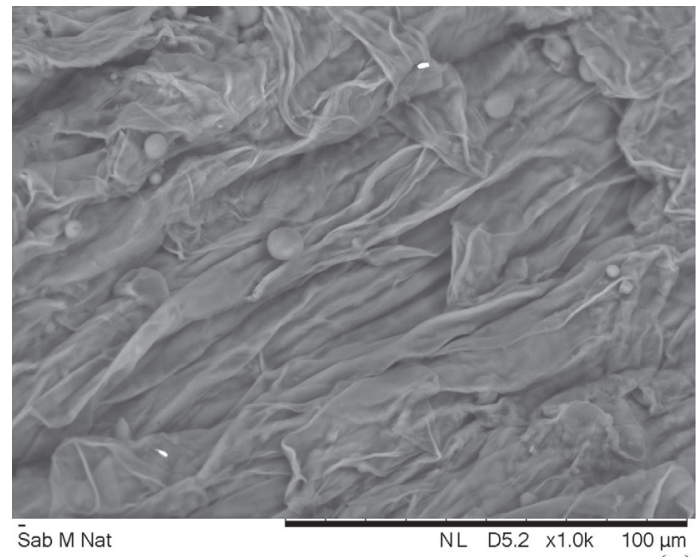

(a)

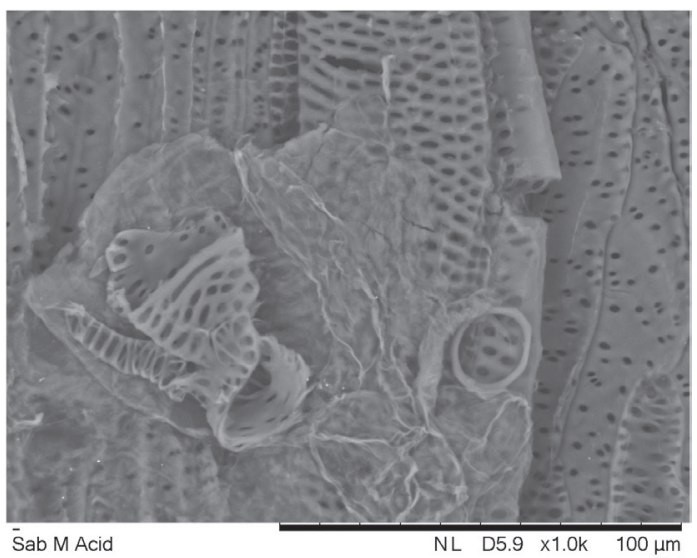

(b)

Figure 5. Micrograph of in natura (a) and pretreated (b) corn cob superficial structure.

structure and decreasing cellulose polymerization and crystallinity degree, which favors enzymes accessibility on the subsequent stage, cellulose hydrolysis.

\section{Enzymatic hydrolysis}

Preliminary study of pretreated organic lignocellulosic waste enzymatic hydrolysis pointed that the residue degradation into reducing sugars begins in approximately $72 \mathrm{~h}$. Conversion was more evident for corn cob, followed by soy peel, cassava peel, corn straw and rice peel. Pure cellulose hydrolysis began in less than $48 \mathrm{~h}$, which is in accordance with what was expected, since it is a pure, and thus, less complex matrix (Figure 6).

Hydrosoluble products output elevated TRS concentration achieving the highest conversion values in $120 \mathrm{~h}$ and a concentration significant decrease when the reaction goes on for more than $140 \mathrm{~h}$ due to saccharides thermodegradation. ${ }^{29}$

Time factor indeed proved to be crucial to estimate the best cellulose conversion using Cellic ${ }^{\circledR} \mathrm{HTec} 2$,

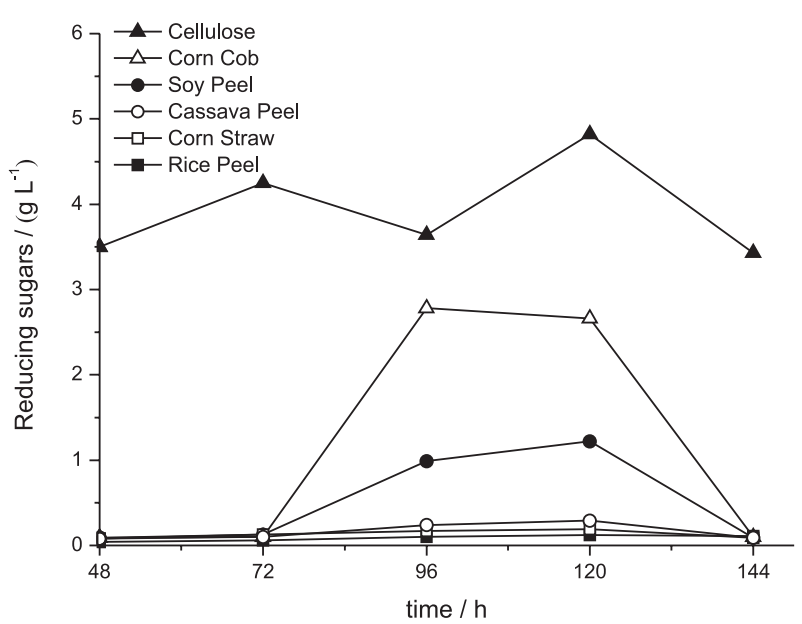

Figure 6. Optimization of reaction time of enzymatic hydrolysis of pretreated lignocellulosic organic wastes.

consolidating an initial and experimental base for this process improvement, which was repeated using biomasses with standardized granulometry below 20 mesh. Figure 7 shows that biomass granulometry reduction increases reaction yield for all biomasses when compared to the 
hydrolysate using granules larger than 20 mesh. Corn straw yield, for example, increased by $1763 \%$ when using lower granulometry. Granulometry reduction, according to Ghasemi et al.,$^{30}$ increases the surface area and decreases polymerization and crystallinity degree for cellulose, which facilitates enzymes accessibility to the substrate.

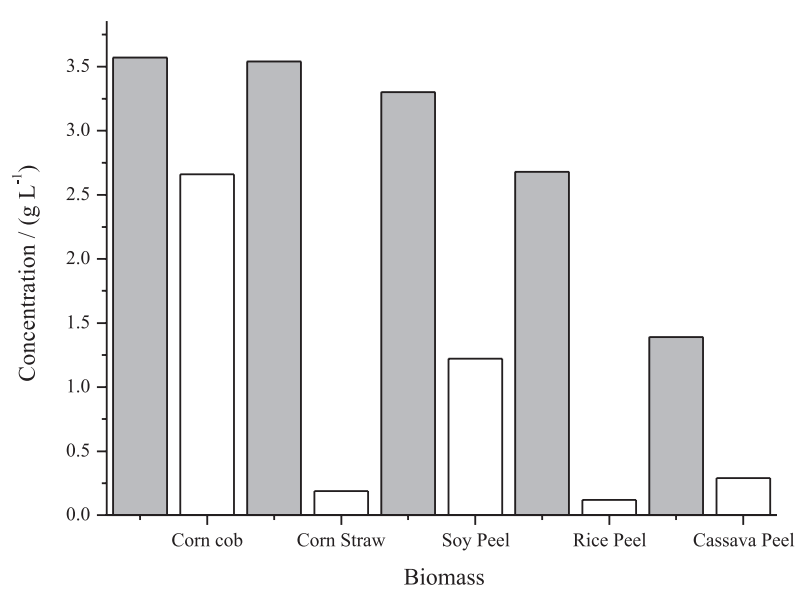

Figure 7. Granulometry effect on enzymatic hydrolysis of lignocellulosic organic waste in $120 \mathrm{~h}$. The gray bars show results for substrates with less than 20 mesh granulometry.

HPLC-RID analysis confirmed glucose presence in the hydrolysates, as shown in Figure 8. Separation of these saccharides mixtures, by the normal method based on ionic exchange using a silica based amino column, allowed elution of two defined peaks, one for glucose in $6 \mathrm{~min}$ and a second one, due to the disaccharide cellobiose in $7 \min ^{31}$

Table 3 compares percentage of glucose content in biomasses before the pretreatment (made in characterization of cellulose step) and after acid pretreatment (using enzymatic hydrolysis). The sugar amount in hydrolysates is expressed in percentage of TRS and selectivity is expressed in percentage of glucose. TRS percentages varies according to biomass type. For corn cob and corn straw, for example, conversion was above $50 \%$, similar to pure cellulose conversion, because of the effective recalcitrance reduction

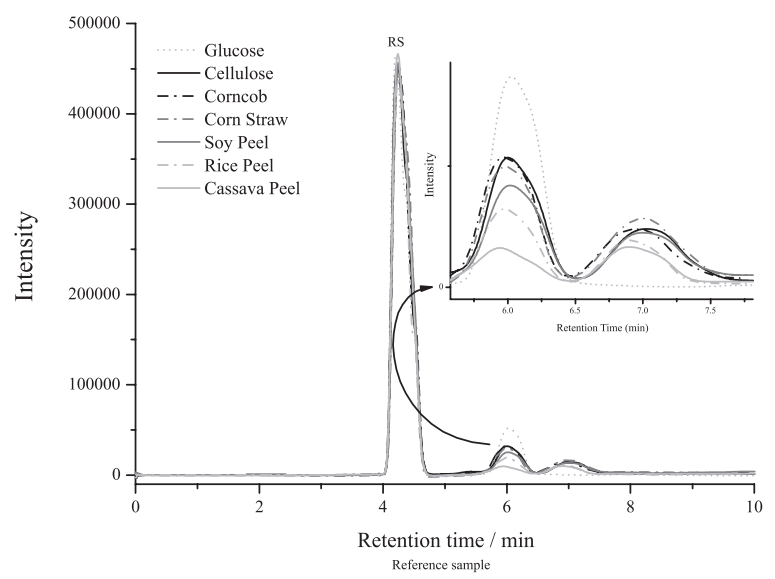

Figure 8. Chromatographic analysis of hydrolysates products.

of these biomasses on pretreatment stage (Figures 4 and 5). Results also indicate that the endo-xylanase enzyme was responsible for the hydrolysis of $\beta$-1,4-glycosidic bonds to glucose in all substrates.

Cassava peel showed the lowest TRS yield and also the lowest conversion to glucose, which suggests the hydrolysis may have also converted disaccharides, corroborating the difficulty to characterize this lignocellulosic residue, that is, both acid and enzymatic hydrolysis indicate that this residue has a high chemical and biological resistance due to high lignin content (50.7\%) (Table 2).

Rice peel also presented a relatively low TRS percentage (38.33\%) due to elevated ash (14.49\%) and lignin contents (29.72\%) (Table 2). High levels of this inorganic material and lignin can act as an inhibitor of catalytic activity.,18

Comparing the acid hydrolyzed (made in characterization step) and the enzymatic, it is possible to observe the increase of glucose content after the pretreatment of soy $((19.06 \pm 2.16)$ and $(30.11 \pm 0.52) \%)$ and corn cob $((24.31 \pm 3.04)$ and $(35.92 \pm 2.47) \%)$. It occurs because of the partial removal of hemicellulose in substrates and the structural modification of lignocellulosic fibers that was evaluated by SEM (Figures 1 and 5), which is possible to observe the changes in rigid and organized surface

Table 3. Total reducing sugars (TRS) percentage and selectiveness in enzymatic hydrolysates of lignocellulosic solid wastes and pure cellulose

\begin{tabular}{lcccc}
\hline Substrate & Glucose content ${ }^{\mathrm{a}} / \%$ & Glucose content $/ \%$ & TRS / \% & Glucose / \% \\
\hline Pure cellulose & - & $35.45 \pm 1.49$ & 53.25 & 66.57 \\
Corn cob & $24.31 \pm 3.04$ & $35.92 \pm 2.47$ & 53.02 & 67.75 \\
Corn straw & $32.80 \pm 1.94$ & $34.11 \pm 1.77$ & 54.88 & 62.16 \\
Soy peel & $19.06 \pm 2.16$ & $30.11 \pm 0.52$ & 46.07 & 65.38 \\
Rice peel & $29.35 \pm 1.64$ & $24.33 \pm 1.14$ & 38.33 & 63.49 \\
Cassava peel & $11.19 \pm 0.56$ & $11.77 \pm 0.24$ & 23.24 & 50.6 \\
\hline
\end{tabular}

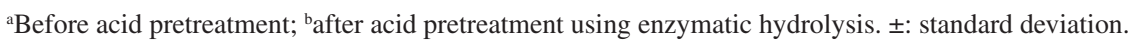


(in natura biomasses) to the fibers that presented pores and cracks (pretreated biomasses).

In contrast, the glucose content in acid hydrolysis and in enzymatic one presented approximately the same values for rice peel $((29.35 \pm 1.64)$ and $(24.33 \pm 1.14) \%)$, cassava peel $((11.19 \pm 0.56)$ and $(11.77 \pm 0.24) \%)$ and corn straw $((32.80 \pm 1.94)$ and $(34.11 \pm 1.77) \%)$. Rice and cassava peels presented high content of lignin in characterization of biomasses step (Table 2) and also low structural changes in lignocellulosic fibers after acid pretreatment (Figures 2 and 3). However, the content of glucose in enzymatic hydrolysis was very similar of acid one which indicate that the yield was very good (Table 3 ).

Lignocellulosic organic residues investigated in this research, specially soy peel and corn straw and corn cob, showed a promising potential to sustainable exploitation for production of glycosidic substances, that can posteriorly be fermented into $2 \mathrm{G}$ ethanol.

\section{Conclusions}

The cellulosic residues of the soy, cassava, rice and corn agro-industries in Maranhão were efficient for fermentable sugar production by enzymatic hydrolysis, mainly soy and corn wastes, and showed that it is possible to use these biomasses to synthesize a higher value-added product, assigning a sustainable destination to such waste.

Rice and cassava biomasses showed the poorest results in enzymatic hydrolysis and in the dilute acid pretreatment, analyzed by SEM, did not show much efficiency since the fiber structures exhibited just a discrete modification. It occurs due the biomasses particulatities because these substrates are very rich in lignin, which is one of the main barriers to access the polysaccharide structure of cellulose.

However, corn and soy substrates have shown to be the most efficient for sugar production, which is directly associated with their chemical composition, since they present appreciable amounts of available cellulose together with a low ash and lignin content that are inhibitors of enzymatic activity.

The use of sugarcane residues has already been applied for the production of cellulosic ethanol by enzymatic hydrolysis owing to this crop high production worldwide and also because it presents more than $40 \%$ of cellulose in its composition. ${ }^{32}$ This paper shows that other biomasses can present such features, specially corn and soy inputs. Thus, using such biomasses is a promising alternative for the production of $2 \mathrm{G}$ ethanol due to its compositional characteristics.

\section{Acknowledgments}

The authors would like to thank Brazilian funding agencies FAPEMA, CNPq and CAPES for encouraging research and technological innovation, as well as the Instituto Federal de Educação Ciência e Tecnologia do Maranhão and the Universidade Federal do Maranhão that contributed to the development of this work.

\section{References}

1. Governo do Maranhão, Secretaria de Estado de Meio Ambiente e Recursos Naturais do Maranhão; Plano Estadual de Gestão dos Resíduos Sólidos do Maranhão - PEGRS MA, Diagnóstico dos Resíduos Agrossilvipastoris I - Orgânicos, vol. 2; Secretaria de Estado de Meio Ambiente e Recursos Naturais do Maranhão, São Luís, Brazil, 2012.

2. Ortiz, L. S.; Energias Renováveis Sustentáveis: Uso e Gestão Participativa no Meio Rural; Núcleo Amigos da Terra/Brazil: Porto Alegre, Brasil, 2005.

3. Lee, H. V.; Hamid, S. B. A.; Zain, S. K.; Sci. World J. 2014, 2014, DOI: $10.1155 / 2014 / 631013$.

4. Isikgor, F. H.; Becer, C. R.; Polym. Chem. 2015, 6, 4497.

5. Nóbile, F. O.; Nunes, H. D.; Rev. Uniara 2014, 17, 89.

6. Yat, S. C.; Berger, A.; Shonnard, D. R.; Bioresour. Technol. 2008, 99, 3855.

7. Lim, H. K.; Kim, D. R.; Lee, K. I.; Hwang, D. W.; Hwang, I. T.; Biomass Bioenergy 2016, 94, 31.

8. Yang, B.; Dai, Z.; Ding, S.; Wyman, C. E.; Biofuel 2011, 4, 421.

9. Gouveia, E. R.; Nascimento, R. T.; Souto-Maior, A. M.; Rocha, G. J. M.; Quim. Nova 2009, 32, 1500.

10. Carvalho, H. H.; Jong, E. V.; Belló, R. M.; Souza, R. B.; Terra, M. F.; Alimentos: Métodos Físicos e Químicos de Análise; Universidade Federal do Rio Grande do Sul: Porto Alegre, Brasil, 2002.

11. Miller, G. L.; Anal. Chem. 1959, 31, 426.

12. Negrulescu, A.; Patrulea, V.; Mincea, M. M.; Ionascu, C.; VladOros, B. A.; Ostafe, V.; J. Braz. Chem. Soc. 2012, 23, 2176.

13. Oliveira, N. T.; Uchôa, S. C. P.; Alves, J. M. A.; Sediyama, T.; Albuquerque, J. A. A.; Souza, E. D.; Melville, C. C.; Pesqui. Agropecu. Bras. 2012, 47, 1436.

14. Ko, J. K.; Um, W.; Woo, H. M.; Kim, K. H.; Lee, S.; Bioresour. Technol. 2016, 209, 290.

15. Tian, S.; Zhao, R.; Chen, Z.; Renewable Sustainable Energy Rev. 2018, 91, 483.

16. Abdelnur, P. V.; Rodrigues, C. M. In Biomassa para Química Verde; Junior, S. V., ed.; Embrapa Agroenergia: Brasília, Brasil, 2013, p. 49.

17. Fonseca, J. S.; Martins, G. A.; Curso de Estatística; Atlas: São Paulo, Brasil, 2006. 
18. Santos, F. A.; Queiroz, J. H.; Colodette, J. L.; Fernandes, S. A.; Guimarães, V. M.; Resende, S. T.; Quim. Nova 2012, 35, 1004.

19. Qin, L.; Li, W.; Liu, L.; Zhu, J.; Li, X.; Li, B.; Yuan, Y.; Biotechnol. Biofuels 2016, 9, 70.

20. Della, V. P.; Hotza, D.; Junkes, J. A.; Oliveira, A. P. N.; Quim. Nova 2006, 29, 1175.

21. Foletto, E. L.; Hoffmann, R.; Hoffmann, R. S.; Portugal Jr., U. L.; Jahn, S. L.; Quim. Nova 2005, 28, 1055.

22. Liu, G.; Bao, J.; Biochem. Eng. J. 2019, 144, 104.

23. Mateus, R. G.; Pereira, L. C.; Jadoski, C. J.; Guilherme, D.; Alves, R. T. B.; Appl. Res. Agrotec. 2018, 11, 79.

24. Xiao, C.; Anderson, C. T.; Front. Plant Sci. 2013, 4, DOI 10.3389/fpls.2013.00067.

25. Martin, A. R.; Martin, M. A.; Mattoso, L. H. C.; Silva, O. R. R. S.; Polim.: Cienc. Tecnol. 2009, 19, 40.

26. Isaac, A.; Barboza, V.; Sket, F. I.; D’Almeida, J. R. M.; Montoro, L. A.; Hilger, A.; Manke, I.; Biotechnol. Biofuels 2015, 8, 40.
27. Lindeboom, N.; Chang, P. R.; Tyler, R. T.; Starch/Stärke 2004, 56,89 .

28. Mood, S. H.; Golfeshan, A. H.; Tabatabaei, M.; Jouzani, G. S.; Najafi, G. H.; Gholami, M.; Ardjmand, M.; Renewable Sustainable Energy Rev. 2013, 27, 77.

29. Tavares, J. T. Q.; Cardoso, R. L.; Costa, J. A.; Fadigas, F. S.; Fonseca, A. A.; Quim. Nova 2010, 33, 805.

30. Ghasemi, M.; Tsianou, M.; Alexandridis, P.; Agric. Res. Technol. 2018, 16, DOI 10.19080/ARTOAJ.2018.16.555985.

31. Cass, Q. B.; Cassiano, N.; Cromatografia Líquida: Novas Tendências e Aplicações; Elsevier: Rio de Janeiro, Brasil, 2015.

32. Rocha, G. J. M.; Gonçalves, A. R.; Oliveira, B. R.; Olivares, E. G.; Rossel, C. E. V.; Ind. Crops Prod. 2012, 35, 274.

Submitted: February 4, 2019 Published online: May 23, 2019 